\title{
The Mediating Effect of External Audit Quality on the Relationship Between Corporate Governance and Creative Accounting
}

\author{
Nofan Hamed Al-Olimat ${ }^{1} \&$ Mohannad Obeid Al Shbail ${ }^{1}$ \\ ${ }^{1}$ Department of Accounting, Faculty of Economics and Administrative Sciences, Al al-Bayt University, Jordan \\ Correspondence: Mohannad Obeid Al Shbail, Department of Accounting, Faculty of Economics and Administrative \\ Sciences, Al al-Bayt University, Jordan.
}

Received: August 29, 2020

Accepted: October 23, 2020

Online Published: December 24, 2020

doi:10.5430/ijfr.v12n1p149

URL: https://doi.org/10.5430/ijfr.v12n1p149

\begin{abstract}
The study aimed to examine the impact of corporate governance in limiting creative accounting practices mediating by the quality of external audits in Jordanian industrial public shareholding companies. The analysis in this research was to follow some of the analysis techniques namely; validity, reliability, and multiple regression were used in order to achieve the objectives of the study, The study population consisted of all Jordanian industrial public shareholding companies registered in the Amman Stock Exchange for the year 2019, and due to the large size of the study population, the researchers applied the s sample random technique representing the population where valid questionnaires reached statistical analysis (120) a questionnaire that included; financial managers and heads of accounting and audit departments. The study concluded that there is a statistically significant effect of the quality of external auditing and the principles of institutional governance in limiting creative accounting practices in Jordanian industrial companies, and in light of these results, the study recommended that industrial companies exploit the positive complementary relationship between the quality of external auditing and the principles of institutional governance to reach the common goal to reduce creative accounting practices.
\end{abstract}

Keywords: external audit quality, principles of corporate governance, creative accounting, Jordanian industrial companies

\section{Introduction}

The need for institutional governance emerged at the local and global levels after a series of financial scandals that affected several international financial companies, which prompted the establishment of monitoring mechanisms to provide more protection to external parties, especially investors, through the adoption of a group of the administrative and financial rules and procedures, relying on a set of policies and methods to preserve the rights of shareholders and other stakeholders and secure the necessary protection for them within the organization (Antonioet al., 2018).

Rughoobur (2018) claimed that the governance is of key importance by protecting the institution from future risks that may be exposed. It is adherence to the principle of integrity and transparency in its internal and external transactions that have a major role in enhancing its position and building confidence for its management through the credibility of its financial reports. Pengilley and Kelly (2018) add another importance to governance through the non-interference of the Board of Directors or any other party with the external auditor who should enjoy Independence, impartiality, and objectivity.

With the intensity of competition between companies, some departments resorted to many incorrect practices to achieve personal benefits at the expense of other parties, to influence the parties with accounting numbers and give an incorrect positive picture of the results of their business through the use of creative accounting practices. Where Almoneef and Samontaray (2019) considered that corporate governance is important to solve the problem of the parties 'control within the company over administrative or financial decisions and to reduce the impact of this on the financial statements and thus reduce the tension of stakeholders towards the reliability of the financial statements. Kang, Hwang, and Hur (2019) focused on the importance of appointing a group of non-executive members and their guest to appoint an external auditor and determine its fees to increase independence when expressing an opinion on the financial statements issued by companies. Ghadhab, Matrood, and Hameed (2019) pointed that there is need to the development of the profession of external auditing and improving the quality of its services to protect the public 
interest and restore the confidence of investors in the financial markets, where Grossi, Papenfuß, and Tremblay (2015) explained that the concept of quality of external audit is closely linked to trust in the financial statements free of Creative accounting practices by companies following corporate governance principles. Through what the researchers reviewed from the above on the importance of the study in general and the research sector in particular, the study problem came to answer the following question: Is there an effect of institutional governance in limiting creative accounting practices in light of the quality of the external audit? Whereas, previous studies tested the effect of institutional governance in limiting creative accounting practices and the effect of external audit quality on the limiting of creative accounting practices, but none of the previous studies studied the effect of external audit quality as a mediating variable between the principles of institutional governance and limiting practices of creative accounting in the Jordanian public shareholding companies.

\section{Theoretical Framework and Literature Review}

\subsection{Corporate Governance}

As a result of the continuous development in the financial operations of companies, the need has become necessary to use the principles of corporate governance by boards of directors to exercise their oversight function efficiently, effectively, and with a high degree of independence. There are many definitions of corporate governance. For instance; Freeland (2007) defined the corporate governance as a way to ensure for everyone that the management of the company care of interests of all parties in the matter of the company. McCahery, Sautner, and Starks (2016) suggested that the need to create a control system that works efficiently and effectively on the company's assets and resources.

\subsection{Corporate Governance Principles}

The Guide to Institutional Governance in Jordan (JLGC, 2017) pointed that there are several principles of institutional governance, namely: justice in treatment with all relevant parties, regardless of their nationalities or sizes, and the right to defend their rights if they are violated. As well as the disclosure and transparency of all matters relating to the facility, such as the financial situation, ownership and control, and of fundamental influence, and the provision of appropriate and modern means of communication to display information at the appropriate time. Also, the owners of the authority are subject to accountability and accountability, as the shareholders hold the Board of Directors accountable within the limits of this responsibility. Likewise, responsibility in terms of a clear separation of responsibilities, a delegation of powers to the Board of Directors, its legal duties and method of selecting members is additional to effective oversight of management. The researchers concludes from the above that the application of the governance system is one of the most important pillars in the establishments for its effective and vital role in preserving the rights of other parties, especially the shareholders, from the administration's misdemeanor of their rights to their interests and also avoiding cases of default and financial and administrative bankruptcy and thus maximizing the wealth of all parties and distributing them fairly.

\subsection{Creative Accounting}

Many researcherss describe that creative accounting is an intentional type that management uses to beautify financial statements and display them without their true image, to serve a specific category, taking advantage of some gaps in international accounting standards, for example, Ali Shah, Butt, and Tariq (2011) defining it as the process of transferring accounting numbers from what it is to what the administration wants to be. Rahayu and Sari (2018) stressed that the administration uses all operations to manipulate financial reports by parties who have understanding and knowledge regarding accounting standards to achieve personal goals. Bora and Saha (2016) mentioned that the most important methods used in creative accounting are as follows:

1. Profits management: this strategy used to achieve specific goals by management or analysts' expectations.

2. Manipulation of financial statements: the function of this strategy is to mislead the users of the financial statements by adding, deleting, or showing wrong data intentionally.

3. Preface income: the aim of this strategy to showing a steady trend in profit growth instead of showing volatile profits.

4. Utilitarian accounting: this used by choosing between specific accounting applications to reach the increase in profits.

\subsection{External Audit Quality}

The external auditor plays a major and important role in the business environment in contemporary organizations, especially in public shareholding companies, where many parties depend on what the auditor provides of services 
beneficial in making decisions.

Many regulations and legislations focused on the quality of external audit because of its prominent role in the credibility of the presentation and financial statements and free from material misstatement. External audit is the extent of compliance with auditing standards and performance standards for individuals in the facility subject to auditing (Haniyeh, 2016). Moreover, External audit quality refers to the extent of the auditor's ability to discover the errors and fundamental irregularities in the financial statements and to announce them to reduce the asymmetry of information between management and shareholders and thus protect the interests of all beneficiaries (Lawrence, Minutti-Meza, \& Zhang, 2011).

\subsection{Factors Affecting Audit Quality}

Hay (2017) mentioned that one of the most important factors affecting the quality of the audit is the auditor's fees if the fees are very low which will be threatening the personal interest on professional competence and the necessary care. Mohammed (2019) pointed to another factor represented in the auditor's qualifications (certificates) and the process (training) as well as the independence of the auditor, both mentally and outwardly, so that there are no motives, pressures or interests when expressing his opinion and the administration does not control the auditor. Also the audit offise size as mentioned by Callen et al. (2020) and claimed that the audit office through procedures for controlling the quality of the audit and the audit team. Wiguna, Yasa, and Suardani (2019) pointed out another factor that affects the quality of the audit, which is professionalism such as performing the tasks with all diligence following technical standards and established professionalism when providing professional services. Also, the experianse factor as mentioned by Sultana, Singh, and Rahman (2019) and argued that the experience increases the probability that the audited financial statements will be free from fundamental errors, which means high quality of the audit.

The researchers believes that some departments resort to using a set of steps to manipulate the financial statements and provide incorrect reports that do not reflect the actual reality, taking advantage of some gaps in accounting principles and policies and financial reporting standards, so proper application of ethical and new methods and standards that accompany modern technological developments must be applied and these ethical standards represent In essence, applying the principles of corporate governance and improving the quality of external audit together, and thus tightening the screws on departments in manipulating financial statements for their interests.

\subsection{Previous Studies}

Several institutional governance studies dealt with its relationship with limiting creative accounting practices. for example, Nuran (2019) conducted the study on Jordanian banks, the result revealed that that there is a positive impact of principles of corporate governance in all its dimensions in limiting the practice of creative accounting. Al-Taweel (2018) examined the effect of complementarity between the application of governance and audit quality, to control profit management practices. The results of the field study showed the positive effect of this integration. And recommended that the absence of this integration leads to the showing of the outputs of the accounting system as not what they are. Ghadhab et al. (2019), invistigated the factors that affect the quality of the external auditor's performance of the Iraqi audit offices. His study found that the need to enhance the role of the external auditor by issuing instructions to adhere to the external audit quality control system to increase confidence in the external auditor's report. (Al-Attar, 2018) found that there is a correlation between the creative accounting and the system of corporate governance to combat fraud, which prevails in most of the economic units in Iraq. He recommended that the need to activate the role of creative accounting and the system of corporate governance, both due to their association and the impact on the eradication of cases of fraud. The results of Tang and Chang (2015) study in the Taiwanese market showed that the profit management has a negative impact on corporate performance, and that effective corporate governance prevents companies to use accounting methods that lead to creative accounting practices. While Iman (2007) aimed to develop a system of institutional governance to enhance the independence of the external auditor. The result of the study showed that there is a direct relationship between the application of corporate governance and the quality of external audit. Tassadaq and Malik (2015) concluded that the corporate governance and ethical values stipulated by international standards are the best way to limit unethical practices and behaviors (creative accounting), since the conflict between the manager and the owner was caused by creative accounting practices.

Given the previous studies, the researchers believes that some studies focused on knowing the relationship of principles of institutional governance in limiting creative accounting practices only, while others tried to know the relationship between the quality of external auditing to limit creative accounting practices. As for this study, the researchers looked at the effect of applying the principles of institutional governance to resuce the practice of 
creative accounting in the presence of mediator factor, which is the quality of external audit. Which helps increase the disclosure of creative accounting practices through the integrative relationship between the principles of corporate governance and the quality of external audit that underpins it? Where the presence of governance and audit external seek to common goal is to limit manipulation departments to their own interests, and thus access to the financial statements reflects the actual reality of the facility. There is no study that takes into account such relationships.

As a result of the above, the study hypotheses can be formulated as follows;

H1: Applying the principles of corporate governance positively infuance the limitation of creative accounting practices in Jordanian public shareholding industrial companies.

$\mathrm{H} 2$ : Applying the principles of corporate governance positively infuance the quality of external auditing in Jordanian public shareholding industrial companies.

H3: The quality of the external audit positively infuance the limitation of creative accounting practices in Jordanian public shareholding industrial companies.

H4: Applying the principles of corporate governance positively infuance the limitation of creative accounting practices mediating by the external auditing quality in Jordanian public shareholding industrial companies.

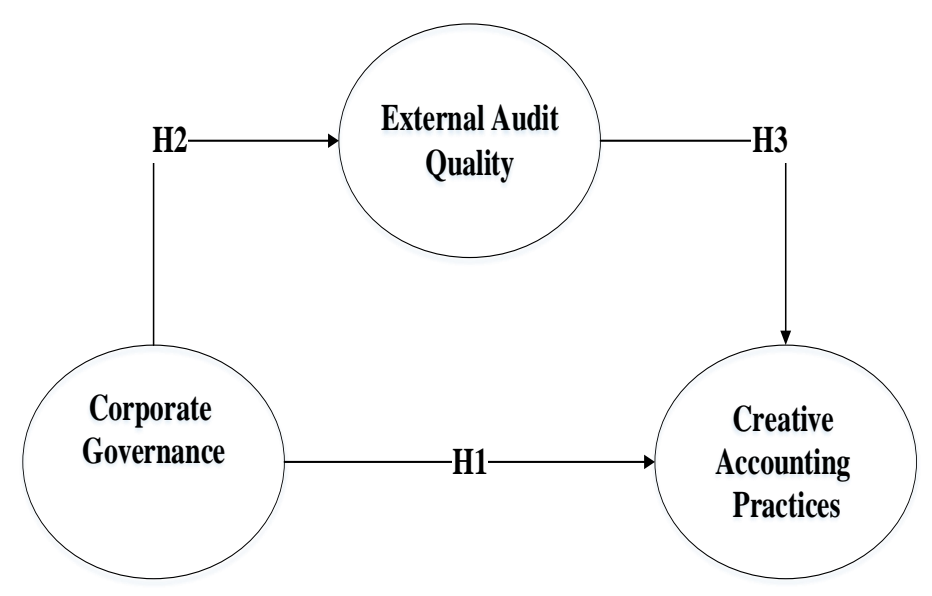

Figure 1. Research model

\section{Methodology}

The study population consists of all the Jordanian industrial shareholding companies registered in the Amman Stock Exchange which count (54) company (Al-Mohareb \& Alkhalaileh, 2019). The researchers adopted a sample random technique because of the large population. The study respondents were financial managers and heads of accounting and audit departments. For the purpose of achieving the goals of the study, the researchers developed a questionnaire specifically prepared for this study, and confirmed the validity and consistency of the questionnaire, then distributed it to the 138 respondents. 127 questionnaires were retrieved, excluded (7) questionnaires which is not valid for analysis. The questionnaires that were used in the statistical analysis amounted to (120) questionnaire, a response rate was $(87 \%)$. The questionnaire consisted of three main sections for measuring study variables, as follows:

The first section: includes (4) items that measure the independent variable (corporate governance) by relying on the instructions of corporate governance for the listed companies for the year 2017 issued by the Jordan Securities Commission (Al-Rahahleh, 2017). The second section: includes (4) items that measure the dependent variable (creative accounting practices) based on the study of (Ababneh \& Aga, 2019). The third section: it includes (4) items that measure the mediator variable (the quality of the external audit) based on the study of (Lin, Wang, \& Chen, 2019). Five Likert Scale was used to measure the questionnaire answers based on the following values: Strongly agree (5), agree (4), natural (3), disagree (2), strongly disagree (1). 


\section{Results}

\subsection{Validity and Reliability}

Average Cronbach Alpha $>0.50$ is reliable, 0.70 is decent, 0.80 is very good and 0.90 is excellent as mentioned by (Al Shbail, Salleh, \& Nor, 2018; Obeid, Salleh, \& Nor, 2017). Table 1 describes Cronbach Alpha from the current study between 0.801 and 0.827 , and the results indicated that all variables have a reliable degree and have achieved and fulfill the rule. However, the factor load should be $(\geq 0.5)$ and the high factor load reflects the high convergence (Al-Shbiel et al., 2018; Al Shbail et al., 2018; Alserhan \& Shbail, 2020; El-dalabeeh, 2019; Obeid et al., 2017). Table 1 shows the loading factors for the Creative Accounting (CA), Corporate Governance (CG), and External Auditor Quality (EAQ) components greater than 0.5 thresholds, and KMO for the study constructs were between 0.699 and 0.772. The results indicated that all formulations check for close compatibility. Refer to Table 1 for the constructs reliability, validity and uni-dimensionality values.

Table 1 . Validity and reliability

\begin{tabular}{|c|c|c|c|c|}
\hline Variable & Factor & & KMO & Cronbach's Alpha \\
\hline \multirow{4}{*}{ Corporate Governance (CG) } & CG1 & 0.906 & \multirow{4}{*}{0.699} & \multirow{4}{*}{0.827} \\
\hline & CG2 & 0.895 & & \\
\hline & CG3 & 0.638 & & \\
\hline & CG4 & 0.804 & & \\
\hline \multirow{4}{*}{ External Auditor Quality (EAQ) } & EAQ1 & 0.857 & \multirow{4}{*}{0.772} & \multirow{4}{*}{0.809} \\
\hline & EAQ2 & 0.884 & & \\
\hline & EAQ3 & 0.624 & & \\
\hline & EAQ4 & 0.817 & & \\
\hline \multirow{4}{*}{ Creative Accounting (CA) } & CA1 & 0.771 & \multirow{4}{*}{0.704} & \multirow{4}{*}{0.801} \\
\hline & CA2 & 0.753 & & \\
\hline & CA3 & 0.769 & & \\
\hline & CA4 & 0.875 & & \\
\hline
\end{tabular}

\subsection{Correlations}

Table 2 shows Pearson's correlation for the variable of the study, which are; Creative Accounting (CA), Corporate Governance (CG), and External Auditor Quality (EAQ). Correlation results indicate a relationship between variables. A positive and significant relationship was found between the External Auditor Quality and Corporate Governance ( $\mathrm{r}$ $=0.662, \mathrm{P}<0.01)$. However, there is a positive relationship between the Creative Accounting and the Corporate Governance $(\mathrm{r}=0.609)$ at level 0.01. Also, found relationship between Creative Accounting and External Auditor Quality $(r=0.276, \mathrm{P}<0.01)$. Meanwhile, the highest relationship was reported between External Auditor Quality and Corporate Governance. This means that the Corporate Governance functions a significant improves when the External Auditor Quality improves.

Table 2. Correlations matrix

\begin{tabular}{lllll}
\hline Variable & $\begin{array}{l}\text { Corporate } \\
(\mathrm{CG})\end{array}$ & $\begin{array}{l}\text { Governance } \\
\text { Quality (EAQ) }\end{array}$ & $\begin{array}{l}\text { External Auditor } \\
\text { (CA) }\end{array}$ \\
\hline Corporate Governance (CG) & 1 & & \\
\hline External Auditor Quality (EAQ) & $0.662^{* *}$ & 1 & 1 \\
\hline Creative Accounting (CA) & $0.609^{* *}$ & $0.276^{* *}$ & \\
\hline
\end{tabular}

**. Correlation is significant at the 0.01 level (2-tailed). 


\subsection{Hypotheses Testing}

In this step the researchers conducting regression analysis, the regression analysis purpose to find the impact of independent variable on dependent variable, and the role of mediator variable. Table 3 illustrates the results of hypotheses testing. The regression results revealed that there were positive and significant relationships between CG and CA. As indicated by the results of the regression test in Table 3, CG construct impact significantly and directly affected CA and it was the predictors of CA. The results also indicated that $31.6 \%$ of the variance in CA was explained by $\mathrm{CG}\left(\mathrm{R}^{2}=0.316, \beta=0.717, \mathrm{P}<0.001\right)$. Therefore, $\mathrm{H} 1$ was supported.

Table 3. Regression analysis for $\mathrm{H} 1$

\begin{tabular}{lllllll}
\hline Independent variable & \multicolumn{6}{l}{ Dependent variable $(\mathrm{CA})$} \\
\cline { 2 - 7 } & Beta $(\beta)$ & t-value & Sig. & $\mathrm{R}^{2}$ & Adjusted R Square & $\mathrm{F}$ \\
\hline CG & 0.717 & 8.176 & 0.000 & 0.316 & 0.311 & 66.844 \\
\hline
\end{tabular}

Moreover, Table 4 illustrates the results of second hypotheses. The regression results revealed that there were positive and significant relationships between $C G$ and EAQ. The results also indicated that $70.9 \%$ of the variance in EAQ was explained by $\mathrm{CG}\left(\mathrm{R}^{2}=0.709, \beta=1.045, \mathrm{P}<0.001\right)$. Therefore, $\mathrm{H} 2$ was supported.

Table 4. Regression analysis for $\mathrm{H} 2$

\begin{tabular}{lllllll}
\hline Independent variable & \multicolumn{6}{l}{ Dependent variable (EAQ) } \\
\cline { 2 - 7 } & Beta $(\beta)$ & t-value & Sig. & $\mathrm{R}^{2}$ & Adjusted R Square & F \\
\hline CG & 1.045 & 18.815 & 0.000 & 0.709 & 0.707 & 354.004 \\
\hline
\end{tabular}

Table 5 illustrates the results of third hypotheses. The regression results revealed that there were positive and significant relationships between EAQ and CA. The results also indicated that $43.9 \%$ of the variance in CA was explained by EAQ $\left(\mathrm{R}^{2}=0.439, \beta=0.644, \mathrm{P}<0.001\right)$. Therefore, $\mathrm{H} 3$ was supported.

Table 5. Regression analysis for $\mathrm{H} 3$

\begin{tabular}{lllllll}
\hline Independent variable & \multicolumn{6}{l}{ Dependent variable $(\mathrm{CA})$} \\
\cline { 2 - 7 } & Beta $(\beta)$ & t-value & Sig. & $\mathrm{R}^{2}$ & Adjusted R Square & $\mathrm{F}$ \\
\hline EAQ & 0.644 & 10.643 & 0.000 & 0.439 & 0.435 & 113.282 \\
\hline
\end{tabular}

Moreover, as shows in table 6 when EAQ was introduced as a mediator, the relationship between CG and CA became insignificant $(\beta=0.011, p>0.05)$. These results indicated that EAQ fully mediated the relationships between $\mathrm{CG}$ and CA. Thus, $\mathrm{H} 4$ was accepted as the data support the notion that EAQ mediated the relationships between CG and $\mathrm{CA}$.

Table 6. Mediation analysis

\begin{tabular}{lllllll}
\hline Independent variable & \multicolumn{6}{l}{ Dependent variable (CA) } \\
\hline & Beta $(\beta)$ & t-value & Sig. & Beta $(\beta)$ & t-value & Sig. \\
\hline CG & 0.717 & 8.176 & 0.000 & 0.011 & 0.116 & 0.908 \\
\hline Mediating Variable (EAQ) & & & & 0.633 & 5.620 & 0.000 \\
\hline
\end{tabular}




\section{Conclusions}

This study aimed to identify the mediating effect of external audit quality on the relationship between corporate governance and creative accounting. The study revealed several results as follows: the results showed a positive effect of corporate governance on creative accounting which approves the success of corporate governance and its practices in helping the management of companies to reduce the creative accounting compete, which comply with study of Awolowo, Garrow, Clark, and Chan (2018). This research has is considered strong evidence for the positive effect of corporate governance on external audit quality, which complies with study of Saputra and Yusuf (2019). Moreover, the findings indicate that there is a positive effect of external audit quality on creative accounting, which comply with study of Khaneja, Bhargava, and Gupta (2017). This research is the first to be able to report that the external audit quality had a full mediating effect on the relationship between corporate governance and creative accounting in the Jordanian Industrial Public Shareholding Companies. Based on the results of this research, the researchers reached several recommendations such as; the Jordanian Industrial Public Shareholding Companies should pay more attention concerning corporate governance to reduce creative accounting as well as implementing the model of this study in other domains.

The key limitation of this research is that it focuses exclusively on one sector of the shareholding firms and, thus, it is important to continue conducting research in order to detect behaviour in other sectors of the economy. Another limitation is that it has been explained in the review of the findings that some of the data used in this study is too aggregated to give a good image of such issues.

\section{References}

Ababneh, T. E., \& Aga, M. (2019). The impact of sustainable financial data governance, political connections, and creative accounting practices on organizational outcomes. Sustainability, 11(20), 5676. https://doi.org/10.3390/su11205676

Al Shbail, M. O., Salleh, Z., \& Nor, M. N. M. (2018). The effect of ethical tension and time pressure on job burnout and premature sign-off. Journal of Business Retail Management Research, 12(4). https://doi.org/10.24052/JBRMR/V12IS04/ART-05

Ali Shah, S. Z., Butt, S. A., \& Tariq, B. (2011). Use or abuse of creative accounting techniques. International Journal of Trade, Economics Finance, 2(6). https://doi.org/10.7763/IJTEF.2011.V2.161

Al-Mohareb, M., \& Alkhalaileh, M. (2019). The association between earnings management and capital structure: an empirical study on Jordanian firms listed in amman stock exchange. International Journal of Economics and Financial Issues, 9(6), 106-112. https://doi.org/10.32479/ijefi.8583

Almoneef, A., \& Samontaray, D. P. (2019). Corporate governance and firm performance in the Saudi banking industry. Banks and Bank Systems, 14(1), 147. https://doi.org/10.21511/bbs.14(1).2019.13

Al-Rahahleh, A. S. (2017). Corporate governance quality, board gender diversity and corporate dividend policy: Evidence from Jordan. Australasian Accounting, Business Finance Journal, 11(2), 86-104. https://doi.org/10.14453/aabfj.v11i2.6

Alserhan, H., \& Shbail, M. (2020). The role of organizational commitment in the relationship between human resource management practices and competitive advantage in Jordanian private universities. Management Science Letters, 10(16), 3757-3766. https://doi.org/10.5267/j.msl.2020.7.036

Al-Shbiel, S. O., Ahmad, M. A., Al-Shbail, A. M., Al-Mawali, H., \& Al-Shbail, M. O. (2018). The mediating role of work engagement in the relationship between organizational justice and junior accountants turnover intentions. Academy of Accounting Financial Studies Journal, 22(1), 1-23.

Al-Taweel, E. (2018). The impact of integration between the rules governance application and audit quality in controlling the practice of earnings management: an applied study. Journal of Financial, Accounting and Management Studies, 2018(9).

Antonio, B. F. N., Enrique, C. N., Guglielmo, C., \& Sara, P. (2018). Governing turbulence, risk and opportunities in the complexity age. Cambridge Scholars Publishing.

Awolowo, I. F., Garrow, N., Clark, M. C., \& Chan, D. (2018). Accounting scandals: Beyond corporate governance. Paper presented at the 9th Conference on Financial Markets and Corporate Governance (FMCG). https://doi.org/10.2139/ssrn.3101057

Bora, J., \& Saha, A. (2016). Investigation on the presence of income smoothing among nse-listed companies. Journal 
of Accounting Research Audit Practices, 15(1), 55.

Callen, J. L., Fang, X., Xin, B., \& Zhang, W. (2020). Capital market consequence of audit office size: evidence from the stock price crash risk. Auditing: A Journal of Practice Theory. https://doi.org/10.2308/ajpt-18-015

El-dalabeeh, A. E.-R. K. (2019). The impact of accounting information systems development on improving e-commerce in the jordanian public shareholding industrial companies. Academy of Accounting and Financial Studies Journal, 23(2), 1-11.

Freeland, C. (2007). Basel committee guidance on corporate governance for banks, stability and development. Paper presented at the Egyptian Banking Institute, Cairo.

Ghadhab, A. K., Matrood, A. K., \& Hameed, A. M. (2019). Factors affecting the quality of external auditor performance: an analytical study of the opinions of auditors working in iraqi audit firms and companies. Academy of Strategic Management Journal.

Grossi, G., Papenfuß, U., \& Tremblay, M.-S. (2015). Corporate governance and accountability of state-owned enterprises. International Journal of Public Sector Management. https://doi.org/10.1108/IJPSM-09-2015-0166

Haniyeh, S. (2016). Factors affecting the quality of auditors in Algeria. Master Thesis, University of Mohamed Biskra, Algeria.

Hay, D. C. (2017). Audit fee research on issues related to ethics. Current Issues in Auditing, 11(2), A1-A22. https://doi.org/10.2308/ciia-51897

Iman, A. (2007). Developing a system for corporate governance in Jordanian corporations to reinforce the independence of the auditor. PhD Dissertation, Amman Arab University.

JLGC. (2017). Institutional Governance in Jordan. Retrieved from https://www.jlgc.com/sites/default/files/2018-12/JLGC\%20Corporate\%20Governance\%20Manual.pdf

Kang, S. M., Hwang, I. T., \& Hur, K. S. (2019). Non-audit services and auditor independence depending on client performance. Australian Accounting Review, 29(3), 485-501. https://doi.org/10.1111/auar.12243

Khaneja, S., Bhargava, V., \& Gupta, L. (2017). Redefining the role of auditor in curbing creative accounting practices. International Journal of Management Social Sciences Research, 6(3), 32-37.

Lawrence, A., Minutti-Meza, M., \& Zhang, P. (2011). Can big 4 versus non-Big 4 differences in audit-quality proxies be attributed to client characteristics?. The Accounting Review, 86(1), 259-286. https://doi.org/10.2308/accr.00000009

Lin, C., Wang, X., \& Chen, Y. (2019). Impact of external audit quality on earnings management in marine enterprises. Journal of Coastal Research, 98(sp1), 100-103. https://doi.org/10.2112/SI98-025.1

McCahery, J. A., Sautner, Z., \& Starks, L. T. (2016). Behind the scenes: The corporate governance preferences of institutional investors. The Journal of Finance, 71(6), 2905-2932. https://doi.org/10.1111/jofi.12393

Mohammed, M. S. (2019). The effect of the external auditor qualifications on improvement the qualitative characteristics of accounting information: A survey study on sample of external auditors of Iraq. Tikrit Journal Of Administrative Economic Sciences, 12(36), 93-105.

Nuran, A.-M. (2019). The impact of corporate governance principles on limiting creative accounting practices in Jordanian commercial banks. Master Thesis, Al al-Bayt University. Retrieved from https://web2.aabu.edu.jo/thesis_site/thes_dtl.jsp?thes_no=5896

Obeid, M., Salleh, Z., \& Nor, M. N. M. (2017). The mediating effect of job satisfaction on the relationship between personality traits and premature sign-off. Academy of Accounting Financial Studies Journal.

Pengilley, A. J., \& Kelly, P. M. (2018). Building the machine: the importance of governance in obesity policy. Frontiers in Public Health, 6, 221. https://doi.org/10.3389/fpubh.2018.00221

Rahayu, S., \& Sari, R. C. (2018). Pengaruh gender, pengetahuan etika profesi akuntan, dan jenis perguruan tinggi terhadap persepsi mahasiswa akuntansi mengenai creative accounting. Jurnal Profita: Kajian Ilmu Akuntansi, $6(4)$.

Rughoobur, S. (2018). An assessment of good corporate governance in state owned enterprises of Mauritius. Studies in Business Economics, 13(1), 166-180. https://doi.org/10.2478/sbe-2018-0013

Saputra, I. G., \& Yusuf, A. (2019). The role of internal audit in corporate governance and contribution to determine 
audit fees for external audits. Journal of Finance, 7(1), 1-5. https://doi.org/10.12691/jfa-7-1-1

Sultana, N., Singh, H., \& Rahman, A. (2019). Experience of audit committee members and audit quality. European Accounting Review, 28(5), 947-975. https://doi.org/10.1080/09638180.2019.1569543

Tang, H.-W., \& Chang, C.-C. (2015). Does corporate governance affect the relationship between earnings management and firm performance? An endogenous switching regression model. Review of Quantitative Finance Accounting, 45(1), 33-58. https://doi.org/10.1007/s11156-013-0427-z

Tassadaq, F., \& Malik, Q. A. (2015). Creative accounting \& financial reporting: model development \& empirical testing. International Journal of Economics Financial Issues, 5(2), 544-551.

Wiguna, I., Yasa, I., \& Suardani, A. (2019). Time budget pressure as moderating variable on the effect of professionalism, experience and audit fee on audit quality. Journal of Applied Sciences in Accounting, Finance, Tax, 2(2), 101-108.

\section{Copyrights}

Copyright for this article is retained by the author(s), with first publication rights granted to the journal.

This is an open-access article distributed under the terms and conditions of the Creative Commons Attribution license (http://creativecommons.org/licenses/by/4.0/). 